Zeszyty Naukowe Szkoły Głównej Gospodarstwa Wiejskiego w Warszawie

Problemy Rolnictwa Światowego tom 18 (XXXIII), zeszyt 1, 2018: 263-274

DOI: $10.22630 /$ PRS.2018.18.1.24

Iwona Szczepaniak ${ }^{1}$

Instytut Ekonomiki Rolnictwa i Gospodarki Żywnościowej - Państwowy

Instytut Badawczy w Warszawie

\title{
Przewagi komparatywne w handlu zagranicznym Polski na przykładzie produktów rolno-spożywczych i pozostałych
}

\section{Comparative Advantages in Polish Foreign Trade on the Example of Agri-Food and Other Products}

\begin{abstract}
Synopsis. Globalizacja i integracja gospodarcza sprawiaja, że konkurencyjność podmiotów coraz częściej analizowana jest w kontekście ich powiązań z rynkiem międzynarodowym. Celem artykułu jest ocena przewag komparatywnych w handlu zagranicznym Polski produktami rolno-spożywczymi na tle handlu pozostałymi produktami. W badaniu wykorzystano wskaźnik relatywnej przewagi handlowej RTA. Badanie to poprzedzono omówieniem wyników handlu zagranicznego. Źródłem danych była baza danych handlowych WITS-Comtrade. Analizę przeprowadzono na poziomie sekcji HS. Badanie udowodniło, że handel zagraniczny Polski charakteryzuje zróżnicowany poziom przewag komparatywnych. Spośród dwudziestu sekcji HS, w 2016 r. Polska posiadała przewagi komparatywne whandlu produktami dwóch rolno-spożywczych i siedmiu pozostałych sekcji. Na sekcje te przypadało odpowiednio ok. $9 \%$ i 50\% wartości obrotów handlowych Polski. Rozwój handlu zagranicznego produktami rolno-spożywczymi Polski, a także dość znaczące przewagi komparatywne w handlu tymi produktami wskazują na konkurencyjność i duże znaczenie polskiego sektora rolnospożywczego dla gospodarki narodowej.
\end{abstract}

Słowa kluczowe: handel zagraniczny, przewagi komparatywne, konkurencyjność, produkty rolno-spożywcze

\begin{abstract}
Because of globalization and economic integration, the competitiveness of entities is more and more often analyzed in the context of their links with the international market. The aim of the article is to assess the comparative advantages in Poland's foreign trade in agri-food products in comparison to trade in other products. The study uses the relative trade advantage indices RTA. This study was preceded by a discussion of the results of foreign trade. The source of data was the WITSComtrade database. The study showed that Poland's foreign trade is characterized by a diversified level of comparative advantages. Of the twenty HS sections, in 2016 Poland had comparative advantages in trade of products from two agri-food sections and seven other sections. These sections accounted for approximately $9 \%$ and $50 \%$ of Poland's trade turnover, respectively. The development of Polish foreign trade in agri-food products, as well as quite significant comparative advantages in trade of these products, indicate the competitiveness and high importance of the Polish agri-food sector for the national economy.
\end{abstract}

Key words: foreign trade, comparative advantages, competitiveness, agri-food products

JEL Classification: F14; L66; Q17

\footnotetext{
${ }^{1}$ dr, Zakład Ekonomiki Przemysłu Spożywczego IERiGŻ-PIB, ul. Świętokrzyska 20, 00-002 Warszawa, e-mail: Iwona.Szczepaniak@ierigz.waw.pl.
} 


\section{Wprowadzenie}

Pojęcie przewagi komparatywnej (względnej) funkcjonuje w ekonomii międzynarodowej od początku XIX wieku i zostało wprowadzone przez Ricardo. Podejście, zgodnie z którym siłą sprawczą handlu międzynarodowego jest wyłącznie zróżnicowanie wydajności pracy między poszczególnymi krajami znane jest w literaturze przedmiotu jako model ricardiański. Zgodnie z tym modelem, handel między dwoma krajami może być dla tych krajów korzystny, jeśli każdy z nich eksportuje dobra, w produkcji których ma przewagi komparatywne. Kraj ma zaś przewagę komparatywną w produkcji jakiegoś dobra wtedy, kiedy koszt alternatywny produkcji w przeliczeniu na inne dobra jest niższy w tym kraju niż w innych krajach. Handel międzynarodowy powoduje zwiększenie światowej produkcji dlatego, że pozwala krajom specjalizować się w wytwarzaniu dóbr, w których mają przewagi komparatywne (Krugman i Obstfeld, 2007, s. 42-44). W tych warunkach każdy kraj biorący udział w wymianie międzynarodowej osiaga korzyści, tj. rozmiary produkcji w każdym z tych krajów są większe niż gdyby nie było handlu między nimi.

Według tej teorii dany kraj może czerpać korzyści z handlu zagranicznego nawet wtedy, gdy nie posiada absolutnej przewagi w produkcji żadnego z dóbr. Wystarczy, żeby posiadał relatywną przewagę $\mathrm{W}$ produkcji wybranego towaru, aby mógł być jego eksporterem. W teorii tej nie porównuje się zatem poziomu jednostkowych kosztów produkcji tego samego towaru w dwóch krajach, lecz porównuje się stosunek jednostkowych kosztów produkcji wybranych dwóch dóbr w dwóch krajach.

Obok przewag komparatywnych typu ricardiańskiego w literaturze funkcjonuje jeszcze drugi typ przewag komparatywnych, tj. przewagi typu Balassy (1965, s. 99-123). Guzek przeciwstawiając sobie oba rodzaje przewag, stwierdza, że: „Przewaga komparatywna w sensie ricardiańskim wynika $\mathrm{Z}$ kryterium opłacalności eksportu danej dziedziny $\mathrm{w}$ porównaniu $\mathrm{z}$ innymi dziedzinami $\mathrm{i}$ jednocześnie $\mathrm{w}$ porównaniu $\mathrm{z}$ zagranicą. Niska przewaga komparatywna nie oznacza jednak, że dany towar nie może być eksportowany. Należy ją interpretować jako wskaźnik świadczący o niskiej predyspozycji specjalizacyjnej w porównaniu z innymi krajami. Przewaga komparatywna typu Balassy wynika natomiast z zastosowania kryterium wielkości eksportu $\mathrm{W}$ porównaniu $\mathrm{z}$ innymi dziedzinami i jednocześnie z zagranicą" (Guzek, 2004, s. 49). W ujęciu Balassy wysokie przewagi mogą zatem ujawniać się nie tylko przy wysokiej opłacalności produkcji i eksportu danej grupy produktów analizowanego kraju, ale także przy niskiej ich opłacalności. Analizę przewag komparatywnych w takim ujęciu można traktować jako przybliżenie zdolności danego kraju do konkurowania w handlu międzynarodowym, a równocześnie podstawę do oceny aktualnej pozycji konkurencyjnej tego kraju i jej zmian w przeszłości. Z tego powodu Misala uważa, że przewagi komparatywne w ujęciu Balassy są raczej przewagami konkurencyjnymi (Misala, 2011, s. 166). Nieustannie rozwijana teoria Balassy i zaproponowane przez niego metody badania przewag komparatywnych stanowią „współcześnie kanon badań międzynarodowej zdolności konkurencyjnej w sferze handlu międzynarodowego i szerzej rozumianej wymiany międzynarodowej” (Misala, 2011, s. 165).

Rozwój procesów globalizacji i integracji gospodarczej sprawia, że konkurencyjność podmiotów gospodarczych coraz częściej analizowana jest w kontekście ich powiązań z rynkiem międzynarodowym. Jednym ze sposobów oceny konkurencyjności polskiego sektora rolno-spożywczego jest analiza przewag komparatywnych $\mathrm{w}$ handlu produktami tego sektora. Celem artykułu jest ocena przewag komparatywnych w handlu zagranicznym Polski produktami rolno-spożywczymi na tle handlu pozostałymi produktami. 
Mimo niewątpliwych zalet teorii kosztów komparatywnych, złożoność i turbulentność procesów zachodzących we współczesnej gospodarce powoduje, że kierunków i nasilenia zmian strumieni handlu nie da się przedstawić za pomocą tylko jednej teorii handlu międzynarodowego. Próbując odpowiedzieć na pytanie, dlaczego dany kraj czy sektor gospodarki odnosi większe sukcesy handlowe i jest bardziej konkurencyjny niż inny, należy nie ustawać w poszukiwaniu nowych zmiennych objaśniających wymianę handlową.

\section{Metoda i dane}

Do badania przewag komparatywnych Balassa zaproponował wskaźnik ujawnionych przewag komparatywnych w eksporcie (RCA - revealed comparative advantage). Badanie na podstawie tego wskaźnika polega na ustaleniu, czy udział danego produktu w eksporcie danego kraju jest wyższy (niższy) od udziału tego produktu w światowym eksporcie na określony rynek (Balassa, 1965, s. 99-123). Wskaźnik ten należy do grupy wskaźników konkurencyjności ex post, tj. odnosi się do pomiaru konkurencyjności w przeszłości. Formuła wskaźnika zaproponowana przez Balassę była w kolejnych latach kilkakrotnie modyfikowana, m.in. przez Vollratha (1991, s. 265-279), Latruffe'a (2010, s. 7-8), czy też Wijnandsa i Verhooga (2016, s. 16).

Uwzględniając doświadczenia poszczególnych badaczy, do oceny przewag komparatywnych Polski w handlu produktami rolno-spożywczymi na tle handlu pozostałymi grupami produktów zdecydowano się wykorzystać wskaźnik relatywnej przewagi handlowej (RTA - relative trade advantage), w postaci logarytmicznej, będacy różnicą wskaźnika ujawnionych przewag w eksporcie (RXA - relative export advantage) oraz wskaźnika ujawnionych przewag $\mathrm{w}$ imporcie (RMA - relative import advantage). W obliczeniach zastosowano następujące wzory (Szczepaniak, 2017, s. 53-54):

$$
\begin{gathered}
R T A_{i P L}=\ln R X A_{i P L}-\ln R M A_{i P L} \\
R X A_{i P L}=\frac{\frac{X_{i P L}}{X_{i w}}}{\frac{X_{P L}}{X_{w}}} \quad \text { (2) } \quad R M A_{i P L}=\frac{\frac{M_{i P L}}{M_{i w}}}{\frac{M_{P L}}{M_{w}}}
\end{gathered}
$$

gdzie:

$R T A_{i P L}$ - wskaźnik relatywnej przewagi w polskim handlu grupą produktów $i$ na danym rynku,

$R X A_{i P L}$ - wskaźnik relatywnej komparatywnej przewagi polskiego eksportu grupy produktów $i$ na dany rynek,

$R M A_{i P L}$ - wskaźnik relatywnej komparatywnej przewagi polskiego importu grupy produktów $i$ z danego rynku,

$X_{i P L} \quad-$ polski eksport grupy produktów $i$ na dany rynek,

$X_{i w} \quad$ - światowy eksport grupy produktów $i$ na dany rynek,

$X_{P L} \quad-$ polski eksport wszystkich grup produktów na dany rynek,

$X_{w} \quad$ - światowy eksport wszystkich grup produktów na dany rynek,

$M_{i P L} \quad$ - polski import grupy produktów $i \mathrm{z}$ danego rynku,

$M_{i w} \quad$ - światowy import grupy produktów $i \mathrm{z}$ danego rynku, 


\section{I. Szczepaniak}

$M_{P L} \quad$ - polski import wszystkich grup produktów z danego rynku,

$M_{w} \quad$ - światowy import wszystkich grup produktów z danego rynku.

Dodatnia wartość wskaźnika RTA (większa od 0) oznacza występowanie ujawnionej przewagi komparatywnej w polskim handlu daną grupą produktów na danym rynku i wskazuje na intensywność tej przewagi, natomiast ujemna jego wartość (mniejsza od 0) wskazuje, że przewaga ta nie występuje. Wskaźnik ten w porównaniu ze wskaźnikiem ujawnionych przewag komparatywnych RCA ma bardziej kompleksowy charakter, gdyż uwzględnia sytuację zarówno w zakresie eksportu, jak i importu danego kraju.

Ocenę przewag komparatywnych $\mathrm{w}$ handlu zagranicznym produktami rolno-spożywczymi Polski na tle pozostałych grup produktów, przeprowadzoną na podstawie wskaźnika RTA, poprzedzono krótkim omówieniem zmian obrotów handlu zagranicznego produktami sektora rolno-spożywczego i pozostałych sektorów gospodarki na tle handlu Polski ogółem oraz analizą salda obrotów handlowych tymi produktami na tle krajowego bilansu handlowego. Okres objęty badaniem obejmuje lata 2004-2016.

Źródłem danych była baza danych handlowych WITS-Comtrade, w której strumienie handlu wyrażone są $\mathrm{w}$ USD. Analizę przeprowadzono na poziomie sekcji HS (Zharmonizowanego Systemu Oznaczania i Kodowania Towarów). Pod pojęciem „produkty rolno-spożywcze” rozumiane są następujące sekcje HS: I - żywiec i produkty pochodzenia zwierzęcego, II - produkty pochodzenia roślinnego, III - tłuszcze i oleje oraz IV - przetwory spożywcze ${ }^{2}$. Pozostałych 16 sekcji HS obejmuje produkty sektorów nie rolno-spożywczych ${ }^{3}$.

\section{Udział produktów rolno-spożywczych w handlu zagranicznym Polski}

Handel produktami rolno-spożywczymi (sekcje HS I-IV) odgrywa istotną rolę w handlu zagranicznym Polski ogółem (Szczepaniak, 2016, s. 36-42). Udział eksportu tych produktów w całkowitym polskim eksporcie na początku członkostwa Polski w UE kształtował się w granicach 9-10\%, następnie wzrósł do ok. 11-12\%, a w latach 2013-2016 oscylował już wokół 13\%. Udział importu produktów rolno-spożywczych w całkowitym polskim imporcie był niższy, w latach 2004-2008 wynosił około 6-7\%, w 2009 r. przekroczył 8\%, a od 2013 r. siega około 9\% (rys. 1). Przewaga eksportu nad importem w analizowanym okresie na ogół zwiększała się - w 2015 r. wyniosła 4,2 pkt proc. (w 2016 r. zmniejszyła się do 3,6 pkt proc.). Handel zagraniczny jest także ważnym czynnikiem rozwoju polskiego sektora rolno-spożywczego (Szczepaniak, 2016, s. 36). Wobec wyższej dynamiki wzrostu produkcji żywności niż krajowego popytu na żywność, większa część przyrostu produkcji sektora była kierowana za granicę. Eksport stał się ważnym sposobem

\footnotetext{
${ }^{2}$ Do Sekcji I. należą nastepujace działy produktów: 01. Zwierzęta żywe; 02. Mieso i podroby; 03. Ryby i owoce morza; 04. Produkty mleczarskie i jaja; 05. Pozostałe produkty zwierzęce. Do Sekcji II. należą następujące działy produktów: 06. Żywe rośliny i kwiaty cięte; 07. Warzywa; 08. Owoce i orzechy; 09. Kawa, herbata, przyprawy; 10. Zboża; 11. Produkty młynarskie, słód, skrobie; 12. Nasiona i owoce oleiste; 13. Ekstrakty roślinne; 14. Pozostałe produkty roślinne. Do Sekcji III. należy następujący dział produktów 15. Tłuszcze i oleje zwierzęce lub roślinne. Do Sekcji IV. należą następujące działy produktów: 16. Przetwory z mięsa i ryb; 17. Cukry i wyroby cukiernicze; 18 . Kakao i przetwory z kakao; 19. Przetwory zbożowe i pieczywo cukiernicze; 20. Przetwory z owoców i warzyw; 21. Różne przetwory spożywcze; 22. Napoje bezalkoholowe i alkoholowe; 23. Odpady i pasze dla zwierząt; 24 . Tytoń i wyroby tytoniowe.

${ }^{3}$ Ostatnia sekcja (XXI - dzieła sztuki i przedmioty kolekcjonerskie) z uwagi na marginalne znaczenie w obrotach handlu zagranicznego została zaliczona do pozycji „Inne”.
} 
zagospodarowania nadwyżek, a tym samym stanowił znaczące źródło wpływów dla krajowego sektora rolno-spożywczego. To z kolei korzystnie oddziaływało na koniunkturę w wielu działach rolnictwa i przemysłu spożywczego.

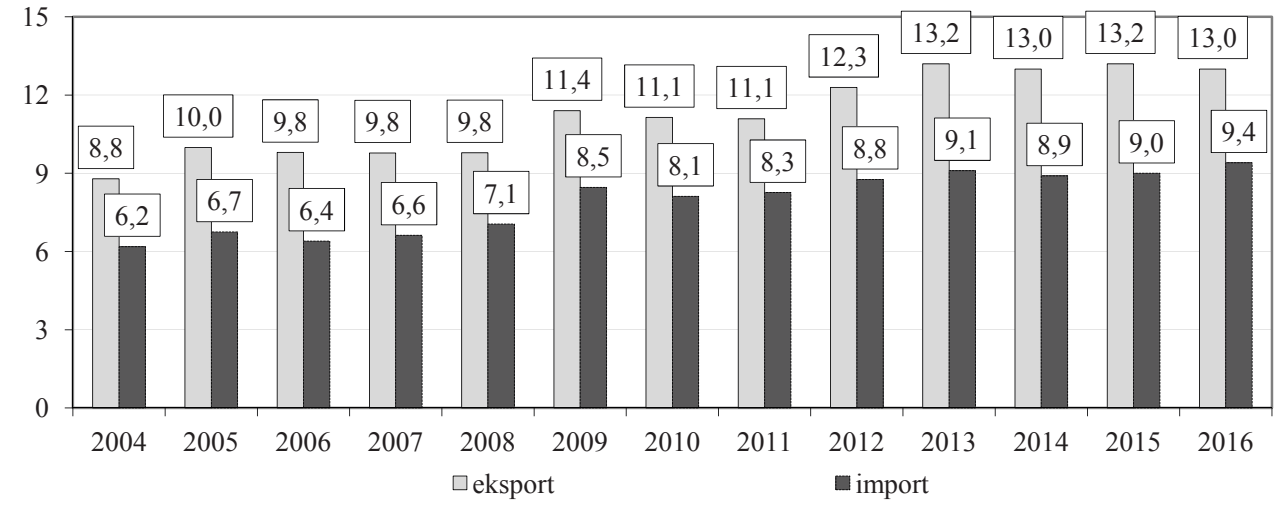

Rys. 1. Udział produktów rolno-spożywczych w handlu zagranicznym Polski ogółem (w \%)

Fig. 1. Share of agri-food products in Polish foreign trade in total (in \%)

Źródło: obliczenia własne na podstawie danych WITS-Comtrade.

Sektor rolno-spożywczy jest jedną z nielicznych gałęzi gospodarki narodowej, która uzyskuje dodatni bilans w wymianie handlowej. Nadwyżka w handlu żywnością korzystnie wpływała na saldo w handlu zagranicznym Polski ogółem (ujemne do 2014 r.), ale jej relatywnie niski poziom ( $\mathrm{w}$ porównaniu $\mathrm{z}$ deficytem $\mathrm{w}$ handlu pozostałymi produktami) sprawiał, że nie miała decydującego wpływu na kierunek zmian tego salda. Dopiero w $2015 \mathrm{r}$. nadwyżka w handlu produktami rolno-spożywczymi $(8,5$ mld USD) pokryła, wyraźnie niższy w tym roku (-3,7 mld USD), deficyt w handlu produktami pozostałych sektorów. W $2016 \mathrm{r}$. po raz pierwszy osiagnięto dodatnie saldo wymiany nie tylko w handlu produktami rolnospożywczymi (7,8 mln USD), ale i pozostałymi produktami (0,1 $\mathrm{mln}$ USD) - por. rys. 2.

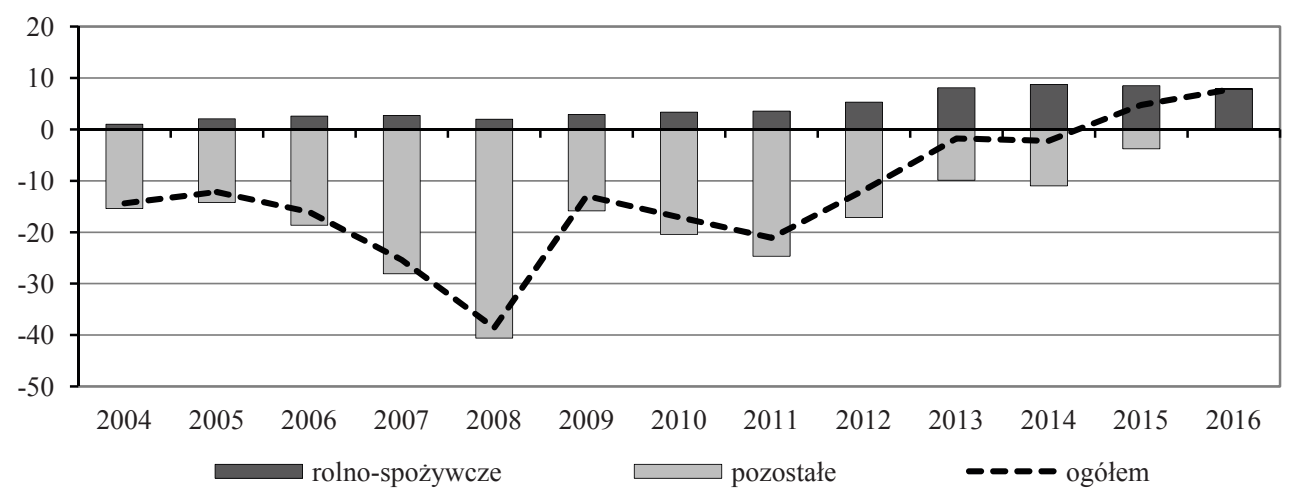

Rys. 2. Saldo handlu produktami rolno-spożywczymi, pozostałymi produktami oraz saldo handlu zagranicznego Polski ogółem (w mld USD)

Fig. 2. Balance of trade in agri-food products, other products and of total Polish foreign trade (in billion USD)

Źródło: obliczenia własne na podstawie danych WITS-Comtrade. 
Reasumując, wymiana handlowa produktami rolno-spożywczymi stanowi ważną część handlu zagranicznego Polski. Udział eksportu żywności w eksporcie ogółem jest wyższy niż importu żywności w imporcie ogółem, a średnioroczne tempo wzrostu polskiego eksportu żywności na rynek światowy jest wyraźnie wyższe niż całego polskiego eksportu. Sektor rolno-spożywczy, będąc działem gospodarki, który generuje wysokie dodatnie saldo w wymianie handlowej, ma duże znaczenie dla krajowego bilansu handlowego i płatniczego.

\section{Handel zagraniczny produktami rolno-spożywczymi Polski na tle handlu pozostałymi grupami produktów}

W latach 2004-2016 produkty rolno-spożywcze (sekcje HS I-IV) stanowiły jedną $\mathrm{z}$ najważniejszych grup towarowych $\mathrm{w}$ handlu zagranicznym Polski. W okresie tym znaczenie tej grupy produktów systematycznie zwiększało się i w 2016 r. udział żywności w polskim eksporcie wyniósł $13,0 \%$ (wobec $8,8 \%$ w 2004 r.), a w imporcie $-9,4 \%$ (wobec $6,2 \%$ w 2004 r.). Spośród poszczególnych sekcji tworzących tę grupę towarową najwyższy udział zarówno w eksporcie, jak i w imporcie miały przetwory spożywcze (IV), a następnie żywiec i produkty pochodzenia zwierzęcego (I) oraz produkty pochodzenia roślinnego (II). We wszystkich tych sekcjach produkcji Polska była znaczącym eksporterem netto, przy czym największym w sekcji przetwory spożywcze. Udział tluszczów i olejów (III) w obrotach handlowych był minimalny, a Polska pozostawała ich trwałym strukturalnym importerem netto (tab. 1).

Do innych najważniejszych grup towarowych (sekcji HS) w handlu zagranicznym Polski należały: maszyny i urządzenia (XVI), sprzęt transportowy (XVII), metale nieszlachetne i wyroby metalurgiczne (XV), tworzywa sztuczne i wyroby z nich (VII), produkty przemysłu chemicznego (VI) oraz różnorodne wyroby przemysłowe (XX). W 2016 r. na grupy te przypadało blisko 70\% polskiego eksportu i 68\% polskiego importu (tab. 1).

Sekcja „maszyny i urządzenia” odgrywa najważniejszą rolę w polskim handlu zagranicznym. W latach 2004-2016 wartość eksportu maszyn i urządzeń zwiększyła się trzykrotnie, do 48,3 mld USD, a importu - przeszło dwukrotnie, do 47,4 mld USD. Tym samym udział maszyn i urządzeń w polskim eksporcie wzrósł o 2,7 pkt proc., tj. do 24,6\%, a w imporcie spadł o 0,1 pkt proc., tj. do 25,1\%. Do 2011 r. oraz w 2015 r. Polska była importerem netto maszyn i urządzeń, w pozostałych latach była ich eksporterem netto (w 2016 r. nadwyżka w handlu tymi produktami przekroczyła 0,9 mld USD).

Sekcja „sprzęt transportowy” jest kolejną ważną grupą towarową w polskim handlu zagranicznym. I chociaż w latach 2004-2016 jej udział zarówno w eksporcie, jak i imporcie obniżył się (odpowiednio o 2,3 i 1,9 pkt proc.), to nadal pozostał znaczący, wynosząc: w eksporcie $15,0 \%$, a w imporcie $11,8 \%$. W analizowanym okresie wartość eksportu środków transportu wzrosła prawie dwuipółkrotnie i na koniec tego okresu sięgnęła 29,4 mld USD. Zmiany w imporcie były mniejsze, jego wartość zwiększyła się blisko dwukrotnie, do 22,2 mld USD. Polska nieprzerwanie notuje nadwyżkę w handlu sprzętem transportowym (w $2016 \mathrm{r}$. wyniosła ona 7,2 mld USD).

Następną grupą towarową w polskim eksporcie są „metale nieszlachetne i wyroby metalurgiczne", z udziałem w latach 2015-2016 w granicach 9-10\%. W imporcie udział tej grupy był nieco wyższy i przekraczał 10\%. W latach 2004-2016 znaczenie tej grupy produktów w eksporcie zmalało (o 3,4 pkt proc., do 9,2\%), a w imporcie pozostało bez zmian 
(10,4\%). Wartość eksportu metali nieszlachetnych i wyrobów metalurgicznych zwiększyła się prawie dwukrotnie, do 18,2 mld USD. Wartość importu wzrosła ponad dwukrotnie, do 19,5 mld USD. Saldo Polski w handlu tą grupą produktów było dodatnie tylko w latach 2004 oraz 2012-2014 (w 2016 r. odnotowano deficyt w wysokości 1,4 mld USD).

Tabela 1. Wyniki handlu zagranicznego Polski w latach 2004 i 2016, według sekcji HS

Table 1. Results of Polish foreign trade in the years 2004 and 2016, by HS section

\begin{tabular}{|c|c|c|c|c|c|c|}
\hline \multirow{3}{*}{ Numer i nazwa sekcji HS } & \multirow{2}{*}{\multicolumn{2}{|c|}{$\begin{array}{c}\text { Eksport } \\
2016\end{array}$}} & \multirow{2}{*}{\multicolumn{2}{|c|}{$\begin{array}{c}\text { Import } \\
2016\end{array}$}} & \multicolumn{2}{|c|}{ Saldo } \\
\hline & & & & & \multirow{2}{*}{\multicolumn{2}{|c|}{$\begin{array}{c}2004 \quad 2016 \\
\text { w mln USD }\end{array}$}} \\
\hline & $\begin{array}{l}\text { w mln } \\
\text { USD }\end{array}$ & $\begin{array}{l}2004 \\
=100\end{array}$ & $\begin{array}{l}\text { w mln } \\
\text { USD }\end{array}$ & $\begin{array}{l}2004 \\
=100\end{array}$ & & \\
\hline Ogółem & 196455,3 & 266,3 & 188517,8 & 213,8 & $-14375,5$ & 7937,5 \\
\hline Produkty rolno-spożywcze & 25532,3 & 393,8 & 17710,2 & 324,8 & 1030,5 & 7822,1 \\
\hline $\begin{array}{l}\text { I. Żywiec i produkty pochodzenia } \\
\text { zwierzęcego }\end{array}$ & 7929,0 & 362,7 & 5215,3 & 483,2 & 1106,7 & 2713,7 \\
\hline II. Produkty pochodzenia roślinnego & 4476,7 & 302,5 & 4390,0 & 244,4 & $-316,9$ & 86,7 \\
\hline III. Tłuszcze i oleje & 645,9 & 1291,8 & 861,0 & 270,0 & $-268,8$ & $-215,1$ \\
\hline IV. Przetwory spożywcze & 12480,7 & 450,9 & 7243,9 & 320,8 & 509,6 & 5236,8 \\
\hline Pozostałe produkty & 170923,0 & 254,0 & 170807,6 & 206,5 & $-15406,0$ & 115,4 \\
\hline V. Produkty mineralne & 5388,2 & 127,4 & 13174,8 & 143,2 & $-4970,5$ & $-7786,7$ \\
\hline VI. Produkty przemysłu chemicznego & 13753,7 & 367,6 & 19105,6 & 217,1 & $-5059,4$ & $-5352,0$ \\
\hline VII. Tworzywa sztuczne i wyroby & 13776,6 & 363,4 & 14650,0 & 222,5 & $-2793,9$ & $-873,4$ \\
\hline VIII. Skóry i wyroby & 1092,1 & 241,4 & 1404,7 & 173,7 & $-356,5$ & $-312,6$ \\
\hline IX. Drewno i wyroby z drewna & 3872,8 & 168,6 & 1374,7 & 169,6 & 1486,2 & 2498,1 \\
\hline X. Ścier drzewny, papier i wyroby & 6471,7 & 273,1 & 5543,5 & 193,1 & $-501,9$ & 928,2 \\
\hline XI. Materiały i wyroby włókiennicze & 7374,0 & 204,2 & 10039,2 & 201,2 & $-1378,8$ & $-2665,2$ \\
\hline XII. Obuwie, nakrycia głowy & 1352,4 & 393,1 & 1757,5 & 391,9 & $-104,6$ & $-405,1$ \\
\hline $\begin{array}{l}\text { XIII. Wyroby z kamienia, ceramiczne, } \\
\text { szkło }\end{array}$ & 3798,4 & 234,9 & 2203,4 & 162,2 & 258,7 & 1595,0 \\
\hline $\begin{array}{l}\text { XIV. Metale i kamienie szlachetne, } \\
\text { perły i wyroby }\end{array}$ & 1297,6 & 374,7 & 501,1 & 486,0 & 243,2 & 796,5 \\
\hline $\begin{array}{l}\text { XV. Metale nieszlachetne i wyroby } \\
\text { metalurgiczne }\end{array}$ & 18168,1 & 196,2 & 19533,7 & 213,8 & 125,1 & $-1365,6$ \\
\hline XVI. Maszyny i urządzenia & 48331,0 & 299,2 & 47402,7 & 213,6 & $-6038,4$ & 928,2 \\
\hline XVII. Sprzęt transportowy & 29424,2 & 230,0 & 22240,7 & 184,2 & 718,0 & 7183,5 \\
\hline XVIII. Przyrządy i aparaty optyczne & 3079,1 & 432,9 & 4456,5 & 266,2 & $-962,7$ & $-1377,5$ \\
\hline XIX. Broń i amunicja & 145,4 & 2203,0 & 212,1 & 401,7 & $-46,2$ & $-66,6$ \\
\hline XX. Różnorodne wyroby przemysłowe & 13391,5 & 241,5 & 4945,8 & 312,9 & 3963,7 & 8445,7 \\
\hline Inne (Sekcja XXI + pozostałe) & 206,3 & 726,4 & 2261,6 & 1379,2 & 12,0 & $-2055,2$ \\
\hline
\end{tabular}

Źródło: obliczenia własne na podstawie danych WITS-Comtrade.

Znaczenie w polskim eksporcie „tworzyw sztucznych i wyrobów z nich” rosło przez większość analizowanego okresu, z 5,1\% w 2004 r. do 7,0\% w 2016 r. W imporcie ich 
udział był nieco wyższy i wahał się w granicach 7,5-7,8\%. W latach 2004-2016 wartość eksportu tworzyw sztucznych i wyrobów z nich zwiększyła się ponad trzyipółkrotnie, do 13,8 mld USD. Wolniej, bo przeszło dwukrotnie, wzrosła wartość polskiego importu tych produktów, do 14,7 mld USD w 2016 r. W całym analizowanym okresie Polska notowała deficyt w handlu tworzywami sztucznymi i wyrobami z nich, ale wykazywał on tendencję malejącą (w 2016 r. wyniósł 0,9 mld USD, wobec 2,8 mld USD w 2004 r.).

Znaczenie sekcji ,produkty przemysłu chemicznego" w polskim eksporcie było podobne jak ,tworzyw sztucznych i wyrobów z nich”. Jej udział w latach 2004-2016 zwiększył się z $5,1 \%$ do 7,0\%. Udział produktów przemysłu chemicznego w polskim imporcie był bardziej stabilny i wynosił ok. 10\%. W analizowanym okresie wartość eksportu produktów przemysłu chemicznego zwiększyła się ponad trzyipółkrotnie, sięgając w 2016 r. 13,8 mld USD. Z kolei wartość ich importu wzrosła ponad dwukrotnie, do 19,1 mld USD. W analizowanym okresie Polska notowała trwały deficyt $\mathrm{w}$ handlu produktami przemysłu chemicznego.

„Różnorodne wyroby przemysłowe” odgrywały ważną rolę przede wszystkim w polskim eksporcie, w $2016 \mathrm{r}$. ich udział wyniósł $6,8 \%$. W imporcie udział tej sekcji produktów był niższy i sięgnął 2,6\%. Wartość obu strumieni handlu w analizowanym okresie wzrosła odpowiednio prawie dwuipół- i ponad trzykrotnie, eksport - do 13,4 mld USD, a import - do 4,9 mld USD. Polska cały czas notowała dodatnie saldo w handlu różnorodnymi wyrobami przemysłowymi.

Analiza wyników handlu zagranicznego Polski, przeprowadzona w układzie głównych grup produktów, upoważnia do stwierdzenia, że produkty rolno-spożywcze należą do najważniejszych sekcji towarowych w handlu zagranicznym Polski, zarówno jeśli chodzi o eksport, jak i import. Większy lub zbliżony udział w eksporcie mają jedynie maszyny i urządzenia oraz sprzęt transportowy, a w imporcie - oprócz maszyn i urządzeń oraz sprzętu transportowego, także metale nieszlachetne i wyroby metalurgiczne oraz produkty przemysłu chemicznego. W latach 2004-2016 dynamika wzrostu obrotów handlu zagranicznego produktami rolno-spożywczymi była jednocześnie znacznie wyższa niż pozostałymi grupami towarowymi. W wymianie handlowej żywnością Polska osiagała wysoką i szybko rosnącą nadwyżkę (względnie porównywalne saldo generował jedynie handel sprzętem transportowym oraz różnorodnymi wyrobami przemysłowymi), która korzystnie oddziaływała na krajowy bilans handlowy i płatniczy.

\section{Ocena przewag komparatywnych Polski w handlu produktami rolno-spożywczymi na tle handlu pozostałymi grupami produktów na podstawie wskaźnika RTA}

W 2016 r. wskaźnik relatywnej przewagi RTA w handlu produktami rolno-spożywczymi Polski wyniósł 0,31 , co oznacza, że Polska posiadała względne przewagi komparatywne w handlu tymi produktami na rynku światowym, a zatem była konkurencyjna na tym rynku. Poziom tych przewag był nieco niższy w porównaniu zarówno z 2004 r., jak i 2015 r. (w latach tych wskaźniki RTA wyniosły odpowiednio 0,36 i 0,37), co wskazywać może jednak na niewielkie pogorszenie pozycji konkurencyjnej polskich producentów żywności na rynku światowym (tab. 2). W 2016 r., spośród czterech sekcji HS obejmujących produkty rolno-spożywcze, wskaźniki RTA wyższe od 
0 występowały w grupie produktów pochodzenia zwierzęcego $(0,33)$ oraz przetworów spożywczych $(0,48)$. Na te sekcje przypadało $8,5 \%$ obrotów polskiego handlu ogółem, a wartość wygenerowanej przez nie nadwyżki wyniosła 8,0 mld USD. W pozostałych sekcjach obejmujących produkty rolno-spożywcze (produkty pochodzenia roślinnego oraz tłuszcze i oleje), wskaźniki RTA były niższe od 0 , a zatem $\mathrm{w}$ handlu tymi grupami produktów Polska nie posiadała przewag komparatywnych.

Tabela 2. Wskaźniki relatywnej przewagi handlowej RTA w handlu zagranicznym Polski w latach 2004, 2015 i 2016, według sekcji HS

Table 2. Relative trade advantage indices RTA in Polish foreign trade, in the years 2004, 2015 and 2016, by HS section

\begin{tabular}{|c|c|c|c|c|}
\hline Numer i nazwa sekcji HS & 2004 & 2015 & 2016 & $\begin{array}{c}\text { Zmiana } \\
\text { w latach } \\
\text { 2004-2016 } \\
\text { w pkt }\end{array}$ \\
\hline Produkty rolno-spożywcze & 0,36 & 0,37 & 0,31 & $-0,05$ \\
\hline I. Żywiec i produkty pochodzenia zwierzęcego & 0,87 & 0,43 & 0,33 & $-0,54$ \\
\hline II. Produkty pochodzenia roślinnego & 0,02 & 0,16 & $-0,01$ & $-0,03$ \\
\hline III. Tłuszcze i oleje & $-1,57$ & $-0,20$ & $-0,34$ & 1,24 \\
\hline IV. Przetwory spożywcze & 0,36 & 0,47 & 0,48 & 0,12 \\
\hline Pozostałe produkty & $-0,03$ & $-0,05$ & $-0,04$ & $-0,01$ \\
\hline V. Produkty mineralne & $-0,40$ & $-0,77$ & $-0,84$ & $-0,44$ \\
\hline VI. Produkty przemysłu chemicznego & $-0,69$ & $-0,32$ & $-0,31$ & 0,38 \\
\hline VII. Tworzywa sztuczne i wyroby & $-0,41$ & $-0,06$ & $-0,09$ & 0,32 \\
\hline VIII. Skóry i wyroby & $-0,43$ & $-0,20$ & $-0,34$ & 0,09 \\
\hline IX. Drewno i wyroby z drewna & 1,30 & 1,02 & 1,03 & $-0,27$ \\
\hline X. Ścier drzewny, papier i wyroby & $-0,03$ & 0,10 & 0,11 & 0,14 \\
\hline XI. Materiały i wyroby włókiennicze & $-0,18$ & $-0,49$ & $-0,45$ & $-0,26$ \\
\hline XII. Obuwie, nakrycia głowy & 0,00 & $-0,48$ & $-0,36$ & $-0,36$ \\
\hline XIII. Wyroby z kamienia, ceramiczne, szkło & 0,30 & 0,41 & 0,43 & 0,12 \\
\hline XIV. Metale i kamienie szlachetne, perły i wyroby & 1,43 & 1,00 & 0,92 & $-0,51$ \\
\hline XV. Metale nieszlachetne i wyroby metalurgiczne & 0,19 & $-0,04$ & $-0,10$ & $-0,29$ \\
\hline XVI. Maszyny i urządzenia & $-0,16$ & 0,00 & 0,02 & 0,18 \\
\hline XVII. Sprzęt transportowy & 0,13 & 0,21 & 0,20 & 0,07 \\
\hline XVIII. Przyrządy i aparaty optyczne & $-0,68$ & $-0,54$ & $-0,43$ & 0,25 \\
\hline XIX. Broń i amunicja & $-2,08$ & $-0,65$ & $-0,64$ & 1,44 \\
\hline XX. Różnorodne wyroby przemysłowe & 1,54 & 0,94 & 0,92 & $-0,61$ \\
\hline Inne (Sekcja XXI + pozostałe) & 0,63 & $-3,43$ & $-2,86$ & $-3,48$ \\
\hline
\end{tabular}

Źródło: obliczenia własne na podstawie danych WITS-Comtrade.

W 2016 r. w handlu produktami pozostałych sektorów Polska posiadała relatywne przewagi komparatywne, mierzone wskaźnikiem RTA, w 7 z 16 sekcji HS, na które przypadało łącznie $49,6 \%$ obrotów polskiego handlu ogółem. Sekcje te generowały nadwyżkę w wysokości 22,4 mld USD. Były wśród nich działy o różnym znaczeniu 
w polskim eksporcie, zarówno o stosunkowo wysokim, jak i niskim poziomie zaawansowania technologicznego. Najwyższy wskaźnik przewag komparatywnych w handlu cechował takie sekcje produkcji, jak: drewno i wyroby z drewna $(1,03)$, metale i kamienie szlachetne, perły i wyroby $(0,92)$, różnorodne wyroby przemysłowe $(0,92)$, wyroby z kamienia, ceramiczne, szkło $(0,43)$ oraz sprzęt transportowy $(0,20)$. Ich łączny udział $\mathrm{w}$ polskim handlu sięgał $21,6 \%$. Spośród trzech sekcji o najwyższym udziale w obrotach polskiego handlu (maszyny i urządzenia, sprzęt transportowy oraz metale nieszlachetne i wyroby metalurgiczne), wskaźnikiem relatywnej przewagi RTA kształtującym się poniżej 0 cechował się jedynie handel metalami nieszlachetnymi i wyrobami metalurgicznymi $(-0,10)$. Oznacza, że w wymianie handlowej tymi produktami Polska nie posiadała przewag komparatywnych.

W latach 2004-2016 wskaźniki relatywnej przewagi RTA w handlu Polski zwiększyły się w 2 z 4 grup produktów rolno-spożywczych - nieznacznie w grupie przetworów spożywczych (o 0,12 pkt), a dość znacząco w grupie tłuszczów i olejów (o 1,24 pkt). $\mathrm{W}$ dwóch pozostałych grupach produktów rolno-spożywczych wskaźniki RTA w tym okresie zmniejszyły się - najbardziej w grupie produktów zwierzęcych (aż o 0,54 pkt), a minimalnie w grupie produktów roślinnych (o $0,03 \mathrm{pkt}$ ). Spośród produktów pozostałych sektorów w analizowanym okresie wskaźniki RTA w polskim handlu ogółem wzrosły w 9 z 16 sekcji HS, najbardziej w przypadku broni i amunicji (o 1,44 pkt), a następnie produktów przemysłu chemicznego (o 0,38 pkt) oraz tworzyw sztucznych i wyrobów (o $0,32 \mathrm{pkt}$ ). W tym samym okresie znacząco zmniejszył się wskaźnik relatywnej przewagi RTA w handlu Polski różnorodnymi wyrobami przemysłowymi (o $0,61 \mathrm{pkt}$ ), metalami i kamieniami szlachetnymi, perlami i wyrobami (o $0,51 \mathrm{pkt}$ ) oraz produktami mineralnymi (o $0,44 \mathrm{pkt})$.

Tabela 3. Wskaźniki relatywnej przewagi handlowej RTA w handlu zagranicznym Polski w 2016 r. i ich zmiany w latach 2004 i 2016, według sekcji HS

Table 3. Relative trade advantage indices RTA in Polish foreign trade, in 2016 and its changes in the years 2004-2016, by HS section

\begin{tabular}{|c|c|c|c|}
\hline & \multicolumn{2}{|c|}{ Wskaźnik RTA w 2016 r. } \\
\hline & & powyżej 0 & poniżej 0 \\
\hline 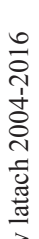 & $\begin{array}{l}\vec{w} \\
0 \\
\stackrel{N}{1} \\
3\end{array}$ & $\begin{array}{l}\text { Przetwory spożywcze (IV) } \\
\text { Ścier drzewny, papier i wyroby (X) } \\
\text { Wyroby z kamienia, ceramiczne, szkło (XIII) } \\
\text { Maszyny i urządzenia (XVI) } \\
\text { Sprzęt transportowy (XVII) }\end{array}$ & $\begin{array}{l}\text { Tłuszcze i oleje (III) } \\
\text { Produkty przemysłu chemicznego (VI) } \\
\text { Tworzywa sztuczne i wyroby (VII) } \\
\text { Skóry i wyroby (VIII) } \\
\text { Przyrządy i aparaty optyczne (XVIII) } \\
\text { Broń i amunicja (XIX) }\end{array}$ \\
\hline 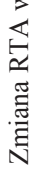 & $\begin{array}{l}\frac{\pi}{0} \\
\text { क्ष } \\
\text { के }\end{array}$ & $\begin{array}{l}\text { Żywiec i produkty pochodzenia zwierzęcego (I) } \\
\text { Drewno i wyroby z drewna (IX) } \\
\text { Metale i kamienie szlachetne, perły i wyroby (XIV) } \\
\text { Różnorodne wyroby przemysłowe (XX) }\end{array}$ & $\begin{array}{l}\text { Produkty pochodzenia roślinnego (II) } \\
\text { Produkty mineralne (V) } \\
\text { Materiały i wyroby włókiennicze (XI) } \\
\text { Obuwie, nakrycia głowy (XII) } \\
\text { Metale nieszlachetne i wyroby metalurgiczne (XV) }\end{array}$ \\
\hline
\end{tabular}

Źródło: opracowanie własne na podstawie danych WITS-Comtrade.

Jednoczesne uwzględnienie wskaźników relatywnej przewagi RTA w handlu Polski ogółem w 2016 r. oraz ich zmian w latach 2004-2016 pozwala wyróżnić cztery grupy sekcji 
HS (tab. 3). Pierwsza z nich to sekcje posiadające relatywne przewagi komparatywne w handlu w 2016 r., które to przewagi w analizowanym okresie się umocniły. Z punktu widzenia konkurencyjności jest to niewątpliwie najkorzystniejsza sytuacja. Do grupy tej zakwalifikowano pięć sekcji, w tym jedną należąca do sektora rolno-spożywczego przetwory spożywcze (IV). Druga grupa obejmuje sekcje HS posiadające relatywne przewagi komparatywne w handlu w 2016 roku, które to przewagi w latach 2004-2016 uległy jednak zmniejszeniu. Sekcji takich było cztery, w tym jedna należąca do sektora rolno-spożywczego - produkty pochodzenia zwierzęcego (I). Kolejna grupa zawiera sekcje, które mimo poprawy w analizowanym okresie wskaźnika RTA, nie zdołały osiagnąć w 2016 r. minimalnych relatywnych przewag komparatywnych. W grupie tej znalazło się sześć sekcji HS, w tym jedna należąca do sektora rolno-spożywczego - tłuszcze i oleje (III). Ostatnia kombinacja wartości wskaźnika RTA w 2016 r. i jego zmian w latach 2004-2016 obejmuje te sekcje, w których nastapiło pogorszenie relatywnej przewagi w handlu, przy braku tej przewagi w 2016 r. W handlu Polski ogółem sytuacja ta wystąpiła w obrotach pięcioma grupami produktów, w tym produktami pochodzenia roślinnego (II). Z punktu widzenia konkurencyjności jest to niekorzystna sytuacja.

\section{Podsumowanie}

W latach 2004-2016 wartość obrotów handlowych Polski produktami rolno-spożywczymi wzrosła ponad trzyipółkrotnie, przekraczając w 2016 r. 43 mld USD. W tym samym okresie eksport żywności zwiększył się czterokrotnie - do 25,5 mld USD, a jej import wzrósł ponad trzykrotnie - do 17,7 mld USD. Sektor rolno-spożywczy był jednym z niewielu sektorów gospodarki narodowej o dodatnim saldzie wymiany handlowej. Nadwyżka Polski w handlu żywnością, wobec w większości lat deficytu w handlu pozostałymi produktami, korzystnie wpływała na krajowy bilans handlowy.

W 2016 r. wskaźniki relatywnej przewagi RTA w polskim handlu produktami rolno-spożywczymi i pozostałymi produktami wyniosły odpowiednio 0,31 i $-0,04$. Oznacza to, że Polska posiadała względne przewagi komparatywne i była konkurencyjna na rynku światowym w handlu produktami rolno-spożywczymi i nie posiadała takich przewag w łącznym handlu pozostałymi produktami. Jeśli chodzi o poszczególne sekcje produkcji, handel zagraniczny Polski charakteryzował się jednak zróżnicowanym poziomem przewag komparatywnych. Spośród dwudziestu sekcji HS, w 2016 r. Polska posiadała ujawnione przewagi komparatywne (wskaźnik RTA > 0) $\mathrm{w}$ handlu produktami dziewięciu sekcji (dwóch rolno-spożywczych i siedmiu pozostałych). Na produkty te przypadało odpowiednio 8,5\% i 49,6\% wartości obrotów handlowych Polski. Sekcje te generowały nadwyżki w wysokości odpowiednio 8,0 i 22,4 mld USD.

Dynamiczny rozwój polskiego handlu zagranicznego produktami rolno-spożywczymi w okresie przynależności Polski do Unii Europejskiej, a także dość znaczące przewagi komparatywne w handlu tymi produktami - wobec handlu pozostałymi produktami wskazują na konkurencyjność i duże znaczenia polskiego sektora rolno-spożywczego dla gospodarki narodowej. 


\section{I. Szczepaniak}

\section{Literatura}

Balassa, B. (1965). Trade Liberalization and Revealed Comparative Advantage. The Manchester School, 33, 99-123.

Guzek, M. (2004). Międzynarodowe stosunki gospodarcze. Zarys teorii i praktyki handlowej (International Economic Relations. Outline of commercial theory and practice). Poznań: Wydawnictwo WSB w Poznaniu.

Krugman, P.R., Obstfeld, M. (2007). Ekonomia międzynarodowa. Teoria i praktyka (International economics. Theory and practice). t. 1. Warszawa: Wydawnictwo Naukowe PWN.

Latruffe, L. (2010). Competitiveness, Productivity and Efficiency in the Agricultural and Agri-Food Sectors. OECD Food, Agriculture and Fisheries Working Papers, OECD Publishing, nr 30.

Misala, J. (2011). Międzynarodowa konkurencyjność gospodarki narodowej (International competitiveness of the national economy). Warszawa: Polskie Wydawnictwo Ekonomiczne.

Szczepaniak, I. (2016). Ocena międzynarodowej pozycji konkurencyjnej sektora rolno-spożywczego na tle innych sektorów polskiej gospodarki (Assessment of the international competitive position of the agri-food sector in comparison to other sectors of the Polish economy) W: I. Szczepaniak (red.) Konkurencyjność polskich producentów żywności i jej determinanty (2), (Competitiveness of Polish food producers and its determinants (2)), Monografie Programu Wieloletniego 2015-2019, nr 38, s. 31-76. Warszawa: IERiGŻPIB.

Szczepaniak, I. (2017). Przewagi komparatywne w polskim handlu produktami rolno-spożywczymi (Comparative advantages in Polish trade in agri-food products). W: I. Szczepaniak (red.) Konkurencyjność polskich producentów żywności i jej determinanty (3), (Competitiveness of Polish food producers and its determinants (3)), Monografie Programu Wieloletniego 2015-2019, nr 67, s. 45-80. Warszawa: IERiGŻPIB.

Vollrath, T.L. (1991). A theoretical evaluation of alternative trade intensity measures of revealed comparative advantage. Weltwirtschaftliches Archiv, nr 130, s. 265-279.

Wijnands, J.H.M., Verhoog, D. (2016). Competitiveness of the EU food industry. Ex-post assessment of trade performance embedded in international economic theory. LEI Wageningen UR, February.

WITS-Comtrade (2018), The World Integrated Trade Solution, Comtrade database. Pobrano z: https://wits. worldbank.org/.

Do cytowania / For citation:

Szczepaniak I. (2018). Przewagi komparatywne w handlu zagranicznym Polski na przykładzie produktów rolno-spożywczych i pozostałych. Problemy Rolnictwa Światowego, 18(1), 263-274; DOI: 10.22630/PRS.2018.18.1.24

Szczepaniak I. (2018). Comparative Advantages in Polish Foreign Trade on the Example of AgriFood and Other Products (in Polish). Problems of World Agriculture, 18(1), 263-274;

DOI: $10.22630 /$ PRS.2018.18.1.24 